\title{
Adverse Effect of Unani Pharmacopeial Formulation Habb-E-Shifa
}

\section{Misbahuddin Azhar*}

Research Officer Scientist-III, Regional Research Institute of Unani Medicine (RRIUM), Post Box No 70, Near Head Post Office, Aligarh-202002, India

*Corresponding author: Dr. Misbahuddin Azhar, Research Officer Scientist-III, Regional Research Institute of Unani Medicine (RRIUM), Post Box No 70, Near Head Post Office, Aligarh-202002, India, Tel: +91 9911918113; E-mail: ccrum619@gmail.com

Received date: July 05, 2018, Accepted date: September 27, 2018, Published date: October 04, 2018

Copyright: $@ 2018$ Azhar M. This is an open-access article distributed under the terms of the Creative Commons Attribution License, which permits unrestricted use, distribution, and reproduction in any medium, provided the original author and source are credited.

\begin{abstract}
India has a variety emporium of the medicinal and aromatic plants (MAPs) andhas well established local healthcare tradition still relevant in indigenous health care system; Unani Medical System is one of them. Unani System of Medicine based on Hippocratic theory of humours is well established in India. Simultaneously it is also believed that Unani dosage forms acts on human body in holistic way and do not exhibit the adverse effects. It is true up to some extent but not at all. Unani dosages forms are sometime exhibit adverse effects if not consumed in proper quantity or prepared in proper manner. Habb-e-Shia is a pharmacopoeial preparation and used as Daf-eHumma (Antipyretic), Daf-e-Tashannuj (Anti-Spasmodic), Musakkin-e-Alam (Analgesic) agent in Unani System of Medicine. Habb-e-Shifa has shown some adverse reaction to a female patient suffering with Suda-e-Muzmin (Chronic headache due to rhino-sinusitis).
\end{abstract}

Keywords: Unani medicine; Habb-E-Shifa; Suda-E-Nazli; Chronic rhino sinusitis

\section{Introduction}

According to the survey of World Health Organization (WHO) nearly eighty percent population of developing countries depends on traditional system for their primary healthcare. Hippocratic theory of humours based Unani Medical System of Medicine (UMSM) is well established in India. Simultaneously it is also believed that Unani dosage forms are safe and did not gives any adverse effects to the body. It is truth up to some extent but not at all. Unani dosages are sometimes gives adverse effects if not prepared as per their methods of preparation or if not detoxified before adding in dosage form if it needs. Habb-e-Shifa is a pharmacopoeial preparation and used as antistress and anti-spasmodic, antipyretic, analgesic activity gives some adverse reaction a female patient suffering with Suda-e-Muzmin (chronic headache due to rhino-sinusitis) [1-3].

UMSM is an ancient system of medicine that uses a variety of treatments through herbs mineral and animals resource of drugs. Unani physicians follows two types of treatment regimens based on single herbs and other is compound preparation. Compound preparations may be of classical, pharmacopoeial and propriety/patent. The selections of drug for any ailments depend upon the choice of physicians. At counter there are two types of compound formulations are available one is classical and other one is propriety or patent products of different pharmaceutics companies.

In UMSM therapeutic products (dosages) can be divided into four groups according to their degree of temperament. First degree drugs: First degree drugs do produce pharmacological effects but their effects, in terms of Qualities i.e. hot or cold, are not perceptible. Second degree drugs: The effect of these drugs, in terms of qualities, are perceptible, but not to the extent of altering the normal functioning of the body. Third degree drugs: The effects of these drugs, in terms of qualities, are strong and alter normal functioning of body significantly, but not to the extent of causing harm. Fourth degree drugs: The effects of these drugs are excessively strong and toxic to the extent of being fatal. However, these drugs can be used safely after undergoing specific process of detoxification (Tadber) [1]. Habb-e-Shifa is a compound pharmacopoeial Unani formulation of Tukhm-e-Jauzmasil (Datura metal), Rewand Chini (Rheum emodi Wall.) Zanjabeel (Zingiber officinalis roxb.) Samagh-e-Arabi (Acacia Arabica) ingredients in a particular ratio [3,4]. Tukhm-e-Jauzmasil (Datura metal) belong the Fourth degree of temperament drug, these drugs are used after specialized process of detoxification. The Actions are Sedative, Antispasmodic, Antipyretic, Nervine Stimulant, analgesic, Antitussive and useful in Rhinitis, Headache, Insomnia, etc. [5-7].

\section{Case Presentation}

Here I am going to present an adverse effect of a compound Unani pharmacopoeial drug Habb-e-Shifa used for the allergic conditions in last week of November 2017. A female patient of age 17 year from a Muslim community comes to our GOPD of Regional Research Institute of Unani Medicine (RRIUM) Aligarh for consultation and treatment of light headache, heaviness in head, nasal blockage from last couple of months with some times running nose and sneezing particularly in the morning. The patient was thoroughly examined and interrogated for the severity of headache with time of onset and site of any migration of pain from the site of its origin etc. After examination in GOPD she was provisionally diagnosed with Suda-e-Nazli Muzmin (Headache due to chronic rhino-sinusitis) and prescribed one pharmacopoeial preparations Habb-e-Shifa manufactured by Indian Medicines Pharmaceutical Corporation Limited (IMPCL), a Government of India Enterprises and one propriety product Sinugard of Aldin pharmaceutical, Aligarh. The ingredients, therapeutic actions and uses of Habb-e-Shifa are as follows

\section{Habb-E-Shifa}

Habb-e-Shifa is a pharmacopoeial Unani formulation having following ingredients and their therapeutic (Table 1) actions and uses $[2,3]$. Batch No. IMPUB-250. 


\begin{tabular}{|l|l|l|}
\hline Type & Name & Weight \\
\hline Tukhm-e-Jauzmasil & Datura metal & $60 \mathrm{~g}$ \\
\hline Rewand Chini & Rheum emodi Wall & $40 \mathrm{~g}$ \\
\hline Zanjabeel & Zingiber officinalis roxb. & $20 \mathrm{~g}$ \\
\hline Samagh-e-Arabi & Acacia arabica & $20 \mathrm{~g}$ \\
\hline
\end{tabular}

Table 1: Pharmacopoeial Unani formulation.

\section{Action}

Daf-e-Humma (Antipyretic), Daf-e-Tashannuj (Antisapsmodic), Musakkin-e-Alam (Analgesic), Munawwim (Sedative) [3] etc.

\section{Therapeutic use}

Humma (fever), Takassur-e-Aaza (lethargies), Cold and Coryza, Suda-e-Muzmin (Severe Headache) [3].

\section{Dose}

250 to $500 \mathrm{mg}$.

\section{Sinugard}

Sinugard is available in sachet of $10 \mathrm{gm}$ in the form of granules (Table 2) of following ingredients. The therapeutic action and uses are as follows.

\begin{tabular}{|l|l|l|}
\hline Ustokhuddus & Lavendula steochas & $550 \mathrm{mg}$ \\
\hline Aslas Soos & Glycyrrhiza glabra Linn. & $550 \mathrm{mg}$ \\
\hline Badyan & Foeniculum vulgare & $60 \mathrm{mg}$ \\
\hline Nana5 & Menthol & $60 \mathrm{mg}$ \\
\hline Roughan Eucalyptus & Eucalyptus regnans & $40 \mathrm{mg}$ \\
\hline Nabat Safaid & Sugar & $250 \mathrm{mg}$ \\
\hline
\end{tabular}

Table 2: Therapeutic action and uses of sinugard.

\section{Action and uses}

It is useful in Catarrhal Secretion, Cattarhal Cough, Rhinitis, Sinusitis, Pharyngitis, Bronchitis, and Winnowing (Tanqiya or cleansing) of brain and Eustachian tube. It was also instructed to the patient that the decoction of Sinugard may be prepared by soaking one sachet of granules into hot boiling water for the period of 2-3- minutes.

\section{Dose of the medicines}

Take Habb-e-Shifa (one pill) with Sinugard sachet of 10 gm granules (decoction prepared by soaking of one sachet in 1 cup of boiling water) in the evening and morning empty stomach for the duration of 7 days. Patient was also advice to avoid sore and spices food, cold drinks.

\section{Observation}

Patient started to take the medicines in the evening of same day and also continued till the next day evening. After taking the second dose she feels some difficulty in her vision during reading her books and complaint to her family members but they suggested as per the myth, the Unani drugs are safe and does not gives any adverse reaction. She continued the medicine in the next day morning and evening. After taking the third dose of regimen, she was unable to walk easily with full confidence her vision was so disturbed that she could not see clearly, and feared with light on eyes. Suddenly her parents informed to the physician regarding her complaints. Physician immediately called for examination at Institute. She was examined thoroughly and found that patient experience of discomfort or pain to the eyes due to light exposure or by presence of physical sensitivity and abnormal or irrational fear of light. Her pupil was found slightly dilated and react to the light photophobia. After examination she was advised to discontinue Habb-e-Shifa immediately for next dose and asked the patient to observe herself for next 12 hours for her problem of vision. It was also advised that if there is no improvement in the condition after 12 hours of time immediately consulted to an ophthalmologist. After 12 hours there were slight improvement in her vision and she feels better. She did not feel any problem in her reading and other day to day activities. Her condition was improved gradually in next 12 hours. After passing of 36 hours she is become completely normal as she was, her vision improved and read and write without any difficulty, no vertigo and any kind of sensitivity to light.

\section{Discussion}

If we look on the ingredients of Habb-e-Shifa it reveals that three ingredients are hot and dry of third degree of temperament [5-7]. As per the Unani text Tukhm-e-Jaumasil (Datura metal Linn.) is the chief ingredient of Habb-e-Shifa [4]. It contains hyocyamine, hyoscine, and atropine [4]. In review of the phyto-constituents of the chief ingredient of Habb-e-Shifa it is found that Case report act to direct attention to a possible ADR (or a known ADR in this case). The main function of atropine is well established it dilate the pupil. In this case the pupil of the patient dilated and it causes blurred in her vision, due to this photophobia etc. as the Habb-e-Shiffa was discontinued with immediate effect of re-examination and observation of next 36 hours revealed that the condition $[8,9]$ of patient improved as the concentration of drug decreases. Patient also said after 12 hours of withdrawal of Habb-e-Shifa her vision has been improved and after passing of thirty six hour of discontinuation of Habb-e-Shifa she become almost alright and her vision become perfect as earlier.

\section{Conclusion}

Such kind of ADR serves to stimulate physicians and researchers to be alert for this in their patients and to report suspected cases to regulatory authorities and pharmaceutical companies. The information from this report is suggested that Habb-e-Shifa may be prescribed with instruction if any reaction, immediately report to the authorities. Reporting of such kind of incidences may provide the data for analysis of other herbal drugs for their ADR. So the common people may be advised to take the medicine with care.

\section{References}

1. Al Qanoon (1993) Department of Islamic Studies, Jamia Hamdard, New Delhi.

2. National Formulary of Unani Medicine (2006) Department of AYUSH, Ministry of Health \& Welfare, Govt. of India.

3. Kabiruddin M (1955) Biyaz-e-Kabir. Hikmat Book Depot, Hyderabad 2: 47-48. 
Citation: Azhar M. (2018) Adverse Effect of Unani Pharmacopeial Formulation Habb-E-Shifa. J Pharmacovigil 6: 1000269. doi: 10.4172/2329-6887.1000269

Page 3 of 3

4. Nadkarni KM (1976) Indian Materia Medica. Bombay Popular Prakashan 1: p440.

5. Rafiquddin M (1985) Kunzul Advia-e-Mufrada, Muslim University Publication, Aligarh.

6. Ghani N (1926) Khazainul Advia, Matba Munshi Nawal Kishore, Lucknow 2: 37-39.
7. Ghani N (1926) Khazainul Advia, Matba Munshi Nawal Kishore, Lucknow 4: 136-142.

8. Baitar I (1987) Al Jamaeul Mufradatul Adwiya Wal Aghziya. CCRUM Publication, New Delhi 1: 54-56.

9. Baitar I (1987) Al Jamaeul Mufradatul Adwiya Wal Aghziya. CCRUM Publication, New Delhi 2: 275-285. 